This paper has to be cited as: Martínez-lbáñez, V., Benavente, D., Hidalgo Signes, C. et al. Temperature-Induced Explosive Behaviour and Thermo-Chemical Damage on Pyrite-Bearing Limestones: Causes and Mechanisms. Rock Mech Rock Eng (2020). https://doi.org/10.1007/s00603-020-02278-x

\title{
Temperature-induced explosive behaviour and thermo-chemical damage on pyrite-bearing limestones: causes and mechanisms
}

\author{
V. Martínez-lbáñez ${ }^{1,{ }^{*}}$, D. Benavente ${ }^{2}$, C. Hidalgo Signes $^{1}$, R. Tomás ${ }^{3}$, M.E. Garrido ${ }^{1}$ \\ * Corresponding author
}

(1) Department of Geological and Geotechnical Engineering. Universitat Politècnica de València. Camí de Vera s/n, E-46071 Valencia, Spain.

(2) Department of Earth and Environmental Sciences, Faculty of Science. Universidad de Alicante. P.O. Box 99, E-03080 Alicante, Spain.

(3) Department of Civil Engineering. Escuela Politécnica Superior de Alicante. Universidad de Alicante. P.O. Box 99, E-03080 Alicante, Spain.

\begin{abstract}
In this investigation, two different varieties of 'Prada' limestones were studied: a dark grey texture, bearing quartz, clay minerals, organic matter and pyrites, and a light grey texture with little or no presence of such components. We have observed two effects of different intensity when heating the dark texture from $400^{\circ} \mathrm{C}$ : i) the explosion of certain samples and ii) greater thermal damage than in the light grey texture. Chemical and mineralogical composition, texture, microstructure, and physical properties (i.e. colour, open porosity, $\mathrm{P}$ and S-wave velocity) have been evaluated at temperatures of 105,300 , 400 and $500^{\circ} \mathrm{C}$ in order to identify differences between textures. The violence of the explosive events was clear and cannot be confounded with ordinary splitting and cracking on thermally-treated rocks: exploded samples underwent a total loss of integrity, displacing and overturning the surrounding samples, and embedding fragments in the walls of the furnace, whose impacts were clearly heard in the laboratory. Thermogravimetric results allowed the identification of a process of oxidation of pyrites releasing $\mathrm{SO}_{2}$ from $400^{\circ} \mathrm{C}$. This process jointly with the presence of micro-fissures in the
\end{abstract}


dark texture, would cause a dramatic increase in pore-pressure, leading to a rapid growth and coalescence of microcracks that leads to a process of catastrophic decay in rock integrity. In addition to the explosive events, average ultrasound velocities and open porosity showed a greater variation in the dark grey texture from $400^{\circ} \mathrm{C}$. That results also points towards a significant contribution of oxidation of pyrites on the thermochemical damage of the rock, among other factors such as the pre-existence of microfissuresand the thermal expansion coefficient mismatch between minerals. Implications in underground infrastructure and mining engineering works are critical, as the explosive potential of pyrite-bearing limestones bear risk for mass fracturing and dramatic strength decay from $400^{\circ} \mathrm{C}$. Moreover, $\mathrm{SO}_{2}$ released has harmful effects on health of people and the potential to form acid compounds that corrode materials, shortening their durability and increasing maintenance costs.

\section{Keywords}

limestone; pyrite oxidation; thermal treatment; explosive behaviour; thermo-chemical damage 


\section{Introduction}

The variation in physical, mineralogical, and mechanical properties of rock with temperature is an issue of current interest among the scientific community, due to its applicability in different fields of engineering and architecture - such as mining (Behnia et al. 2017), geothermal energy (Pei et al. 2018), underground storage of radioactive waste (Zhang et al. 2017a), building materials (Brotóns et al. 2013; Fioretti et al. 2018), tunnelling (Nordlund et al. 2014), and rock drilling (Rossi et al. 2018). As a general overview, an increase in temperature leads to a growth in pores and fissures, and a decrease in ultrasonic wave propagation, uniaxial compression strength, and elastic modulus. Altogether, a temperature increase points to a decay in rock integrity, whose magnitude and key temperatures strongly depend on the type of rocks, and their diverse physical and mineralogical properties.

Limestone is one of the most common types of sedimentary rocks. Its mineralogical composition is mostly calcite, which presents an anisotropic thermal expansion. A decrease in strength limit due to microcracking at relatively low temperatures (up to $250^{\circ}$ C) was described for a limestone from Anstrude (France) (Lion et al. 2005). Below $150^{\circ}$ C, microcracking does not seem to occur according to Yavuz et al. (2010), who observed a marked decay in physical properties (i.e. bulk density, P-wave velocity, and effective porosity) above $400^{\circ} \mathrm{C}$. A clear reduction in uniaxial compression strength (UCS) from $500^{\circ} \mathrm{C}$, and a tendency to redden when heating, were described for calcareous and dolomitic rocks from Apulia in Italy (Andriani and Germinario 2014). Temperatures above $600^{\circ} \mathrm{C}$ usually mark a dramatic decline in UCS (Sengun 2014). Subsequent research contributed by accurately setting the temperature variation ranges for limestones from Linyi, China (Zhang et al. 2017b). These authors indicated that from 200 to $500{ }^{\circ} \mathrm{C}$ the porosity and pore volume rapidly increased, and from 500 to $600{ }^{\circ} \mathrm{C}$ the porous 
parameters were relatively stable. The maximum strength slowly decreased while the peak strain continuously increased, elastic modulus declined quickly, Poisson's ratio dropped suddenly, and the hardness decreased from mid-hard to soft. Recently, research correlated physical and mechanical properties to define a thermal damage factor (Yang et al. 2019).

Different mechanisms control thermal damage of rocks, where the heating/cooling rate plays a fundamental role. On the one hand, a sharp variation of temperature when cooling (quenching) leads to tensile stresses that nucleate cracks (Mallet et al. 2014) even at temperatures below $300^{\circ} \mathrm{C}$ (Kim et al. 2014), causing a reduction on strength and elastic properties and enhancing permeability (Kumari et al. 2018). Such effect can be observed after high local heating rates (i.e. higher than $5^{\circ} \mathrm{C} / \mathrm{s}$ ), where thermal cracking is dominated by the stress concentrations caused by high thermal gradients (Nordlund et al. 2014; Rossi et al. 2018). On the other hand, low heating rates cause thermal cracking in carbonate rocks mainly controlled by the anisotropic expansion of calcite (Sippel et al. 2007; Yavuz et al. 2010). Finally, thermo-chemical damage involves some specific chemical reactions, such as thermal decomposition of calcite that starts at $500^{\circ} \mathrm{C}$, exhibiting the highest decomposition rate around $700^{\circ} \mathrm{C}$, and being complete near $900^{\circ} \mathrm{C}$.

Presence of pyrites may be common in limestones with organic content (Berner 1985), and that gives them a dark tone. Such pyrites could experiment thermal oxidation when limestones are heated. The investigation of pyrite thermal oxidation is important in a wide number of productive fields. The wide occurrence of pyrite in different minerals and coals makes it one of the main sources of $\mathrm{SO}_{2}$ (acid rain precursor) emission from various industrial activities, such as coal conversion (Seehra and Jagadeesh 1981), power production (Lv et al. 2015), and cement production (Hansen et al. 2003; Cheng et al. 
2014). Pyrite in auriferous and carbonaceous matters is usually found in association with valuable metallic elements such as $\mathrm{Au}, \mathrm{Ag}$, and $\mathrm{Cu}$ and their recovery includes the oxidative roasting of raw materials (Zhang et al. 2019). Pyrite is common in sedimentary rocks studied as a potential host rock for radioactive waste like claystone, and its oxidation is harmful to the corrosion kinetics of metallic engineered components (Verron et al. 2019). The oxidation reaction of pyrite is a destabilising factor in commercial emulsion explosive products, due to its exothermic reaction (Xu et al. 2015). In ceramic production, research focuses on reducing sulphur emissions produced when heating clays containing pyrites - which involve defects in the final product (Gómez-Tena et al. 2014).

However, investigations describing thermo-chemical damage on pyrite-bearing rocks are scarce, although this type of rocks is common in civil and mining engineering works. In this research, we study the thermal behaviour of a pyrite-bearing limestone from 'Prada' formation (Spain) to explore the causes and mechanisms of induced thermal damage. To this aim, we evaluate the variation of physical properties (colour, open porosity, $\mathrm{P}$ and S-wave velocities) at different temperatures between 105 and $500^{\circ} \mathrm{C}$; we determine chemical, mineralogical, and microstructure changes; and we pay special attention to the thermal reactions involved and the released gases.

\section{Materials and methodology}

Rock samples were taken from two horizontal boreholes in Organyà, in the Catalan south Pyrenean zone (Spain). Both were drilled in a lower cretaceous limestone formation locally named 'Prada' limestone, widely described by García Senz et al. (2002). The depth explored in horizontal borehole 1 was of $65.30 \mathrm{~m}$ and $91.45 \mathrm{~m}$ in borehole 2 . Intact 
rock showed a bluish grey colour, and two varieties of samples could be clearly distinguished according to their lightness: light and dark grey.

Dark and light grey samples forming 'Prada' limestone were separated in two groups. A total of 20 irregular fragments, with an average volume of $113 \pm 36 \mathrm{~cm}^{3}$, were then randomly selected from each group to determine the physical properties of the intact rock (i.e. dry density, water absorption, unit weight of solids, total and open porosity) and to compare the variation of open porosity with increase of temperature. In addition, a total of 68 cylindrical samples of $63 \mathrm{~mm}$ in diameter and a slenderness of 1.0 and 2.5 were chosen among both dark and light grey specimens to compare thermal damage between textures. Finally, four cylindrical samples were selected from each group to determine UCS for the intact rock. Table 1 depicts the number of samples tested for each group (dark or light grey) and their dimensions. All samples were identified by the borehole number and the depth at which they were extracted (Figure 1). A temperature of $105^{\circ} \mathrm{C}$ was applied to remove moisture content and are considered references for the determination of the intact rock properties.

Table 1. Number of samples tested for each group (dark or light grey) and dimensions. All samples were first heated at $105^{\circ} \mathrm{C}$, then treated at 300,400 and $500^{\circ} \mathrm{C}$. Additional 4 cylindrical samples from each group were used to determine UCS for the intact rock (at $\left.105^{\circ} \mathrm{C}\right)$.

\begin{tabular}{|c|c|c|c|c|}
\hline \multirow{2}{*}{ Temperature } & \multicolumn{2}{|c|}{ Dark grey limestones } & \multicolumn{2}{c|}{ Light grey limestones } \\
\cline { 2 - 5 }$\left({ }^{\circ} \mathrm{C}\right)$ & Irregular & Cylindrical & Irregular & Cylindrical \\
& samples & samples & samples & samples \\
\hline 105 & 15 & 34 & 15 & 10 \\
\hline 300 & 5 & 10 & 5 & 10 \\
\hline 400 & 5 & 10 & 5 & 10 \\
\hline 500 & 5 & 10 & 5 & 5 \\
\hline
\end{tabular}




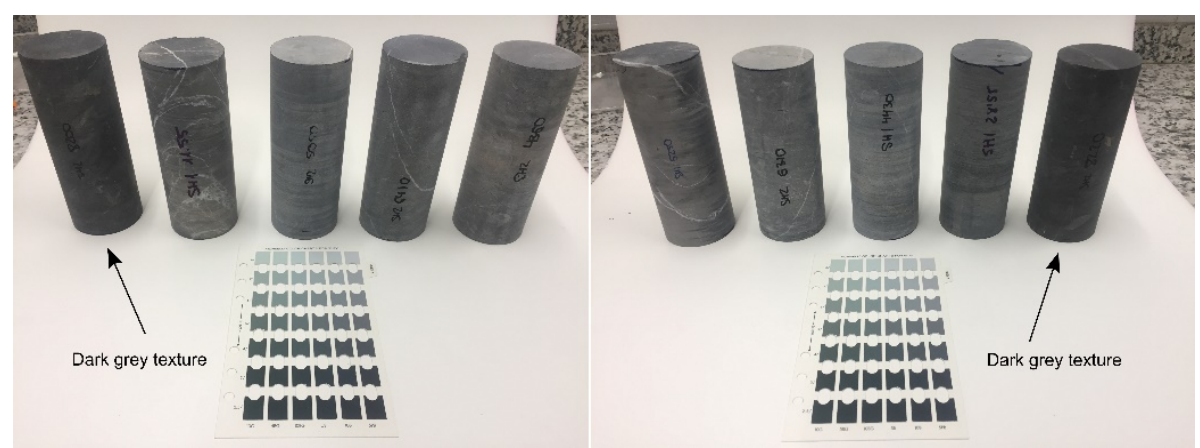

Figure 1. Cylindrical cores from 'Prada' limestones before thermal treatment. Samples with a dark grey texture are identified in the figure.

Samples were subjected to thermal treatment, except those used for UCS tests. The heating process was performed in a furnace under air atmosphere and constant pressure. Temperatures of 300,400 , and $500^{\circ} \mathrm{C}$ were selected and a gradient of $5^{\circ}$ $\mathrm{C} / \mathrm{min}$ was applied. Once the target temperature was reached, it was maintained for one hour. Then, cooling stage started inside the furnace at a slow rate from 5 to $1^{\circ} \mathrm{C} / \mathrm{min}$. Once the temperature inside the furnace reached $300^{\circ} \mathrm{C}$, limestones were then put outside the furnace and naturally cooled at air (at a slow rate) to room temperature $\left(21^{\circ}\right.$ C). It is worth noting that during the heating process, one thermocouple registered the temperature inside the furnace, another thermocouple was in contact with the surface of one cylindrical sample, and a third one was installed inside the sample, in a small drill made along its axis. The evolution of the temperature was registered every minute using a PicoLog 6 data logger. Special attention was paid to perceptible sounds through the furnace chamber indicating explosions of samples during heating, and the temperature at which that occurred. Once the furnace was opened, the explosive events of certain samples had already happened, and the visual damage were recorded.

Fragments from representative dark and light grey rock fractions were then pulverised. Total carbon, sulphur, and sulphides content were determined over pulverised rock 
samples using an IR spectrometer after heating in a furnace. The whole rock analysis was performed using fusion and X-ray fluorescence.

Determination of oxidizable organic matter aims to explain the different coloration between light and dark grey textures. To do so, finely ground rock samples previously subjected to $105^{\circ} \mathrm{C}$ and $500^{\circ} \mathrm{C}$ were selected, and oxidizable organic matter contents were determined using potassium permanganate, according to Spanish standard (UNEEN-103204 2019).

Thermal analyses of dark grey samples were conducted using thermogravimetric, differential thermal analysis, and differential scanning calorimetry, TG-DTA-DSC, and TG-DTA coupled to a mass spectrometer. TG-DTA-MS and TG-DTA-DSC experiments were performed using a NETZSCH STA 449 Jupiter F5 thermal analyser. The NETZSCH Aeölos Quadro Mass Spectrometer was coupled to the TG-DTA analyser. Measurements were conducted under dynamic mode from 25 to $700^{\circ} \mathrm{C}$ at a heating rate $10^{\circ} \mathrm{C} \mathrm{min}{ }^{-1}$ under air conditions $\left(\mathrm{N}_{2}: \mathrm{O}_{2}\right.$ in $\left.4: 1\right)$ at $50 \mathrm{ml} / \mathrm{min}$.

The phase composition of samples was analysed by powder X-ray diffraction (XRD) on a Bruker D8-Advance diffractometer with a Goebel mirror (non-planar samples) using Cu $\mathrm{Ka}$ radiation and a setting of $40 \mathrm{kV}$ and $40 \mathrm{~mA}$. XRD data were collected and interpreted using the XPowder software package, which allows a quantitative analysis for the identified phases.

Optical and scanning electron microscopy (SEM) in backscattered electron mode was used to study the petrographic features of 'Prada' limestone. Thin-section examination was performed under an optical polarising microscope (Model Zeiss Assioscop). For the SEM analysis, sample surfaces were polished with alumina and diamond powder; the finest abrasive was a $0.4 \mathrm{~mm}$ diamond powder. Uncovered polished surfaces were 
studied in a HITACHI S-3000 N variable pressure SEM working at low vacuum, and salt tested surfaces were analysed in a high vacuum SEM in secondary electron mode. The chemical analysis of the elements associated with the SEM images were accomplished using the energy dispersive X-ray (EDX) technique.

Mercury intrusion porosimetry (MIP) was used to obtain fine porosity results and pore size distribution in both dark and light grey samples. Tests were developed with a PoreMaster 60 GT (Quantachrome Instruments). The employed surface tensions and contact angles of mercury were $480 \mathrm{mN} / \mathrm{m}$ and $130^{\circ}$, respectively.

Physical properties of both dark and light grey limestones were determined using irregular samples. Dry density, water absorption, unit weight of solids, total and open porosity, were determined before and after thermal treatment using saturation and buoyancy techniques according to the suggested methods of the International Society for Rock Mechanics (ISRM) (Franklin 1979).

A preliminary colour classification of the intact rock was performed using Munsell soil colour charts (GLEY 2 chart for low chroma colours). To observe colour differences before and after heat treatment, both faces of samples were polished and moistened, and their image captured using an HP OfficeJetPro 7740 scanner with a resolution of 600 ppi. The average SRGB colour values of the pixels were obtained for representative regions of the material using software GIMP 2.10.12. The colour was described in terms of CIELAB space colour (CIE 1977), used by many authors (Pospíšil et al. 2007; González-Gómez et al. 2015) where L* represents lightness (i.e. the darkest black at L* $=0$, and the brightest white at $L^{*}=100$ ), and $a^{\star}$ and $b^{*}$ chromaticity. The $a^{\star}$ axis represents green in the negative direction and red in the positive direction, and $b^{\star}$ axis represents blue in the negative direction and yellow in the positive direction. 
The presence of discontinuities such as pores and fissures, reduces the propagation velocity of the mechanical waves, and so it is a commonly used parameter to evaluate the evolution in rock deterioration. Thus, ultrasonic measurements were carried out over light and dark grey cylindrical samples before and after thermal treatment. The transmission method consists of two piezoelectric sensors coupled to the sample at constant pressure. Compressive $(P)$ and shear $(S)$ waves were measured using polarised Panametric transducers $(1 \mathrm{MHz})$. Emitting-receiving equipment (PanametricsNDT 5058PR) and an oscilloscope (TDS 3012B-Tektronix) were used to acquire and digitalise the waveforms to be displayed, manipulated, and stored. Every measurement of the $\mathrm{P}$ and $\mathrm{S}$ waves was repeated three times to test the reproducibility of the experiments and the corresponding results.

Finally, UCS tests were performed to determine mechanical properties for the intact rock (at $105^{\circ} \mathrm{C}$ ) for both light and grey textures. A slenderness of 2.5 was decided to ensure their suitability according to ISRM suggested methods (Fairhurst and Hudson 1987). Core faces were polished to ensure flatness and perpendicularity relative to the axis. A four-column press machine Mecánica Científica SA model 28.5200 with a capacity of $2000 \mathrm{kN}$ was used. A compression rate of $0.5 \mathrm{MPa} / \mathrm{s}$ was applied until the ultimate load and controlled by MecaTouch software v.1.1. Strain gauges of $30 \mathrm{~mm}$ long Tokyo Measuring Instruments Lab PF-30-11 (120.3 $\pm 0.5 \Omega, k=2.13 \pm 1)$ were used for longitudinal and transverse strains. Values were registered for each loading cycle using MecaSoft software v.1.3.8. The tangent Young's modulus and the corresponding Poisson's ratio were determined from values of $50 \%$ of the sample ultimate load. 


\section{Results}

3.1. Chemical, mineralogical, petrographic and microstructural characterisation

'Prada' limestone is a grainstone or biosparite with abundant bioclasts $(0.2-2 \mathrm{~mm})$ : mainly planktonic foraminifera and minor amounts of molluscs, red algae, bryozoan, and frequently fragmented echinoderm (Figure 2). Some angular and sub-angular grains of monocristalline quartz $(0.02-0.1 \mathrm{~mm})$ are also present. Sub-rounded grains of iron sulphides (0.02-0.04 $\mathrm{mm}$ ) are irregularly distributed in the limestone (Figure 2A). They can be found dispersed in the rock matrix and concentrated in grain borders, cement, or stylolites. Cement is abundant and mainly consists of micro and meso-crystalline mosaics of calcite spar. Cement fills interparticle (bioclasts) porosity. Syntaxial cement is related to fragmented echinoderms. Micritic matrix is minor $(<5 \%)$ and irregularly distributed. Discontinuities are abundant and consist of fissures, calcite veins and a minor amount of stylolites (Figure 2E and Figure 2F). 

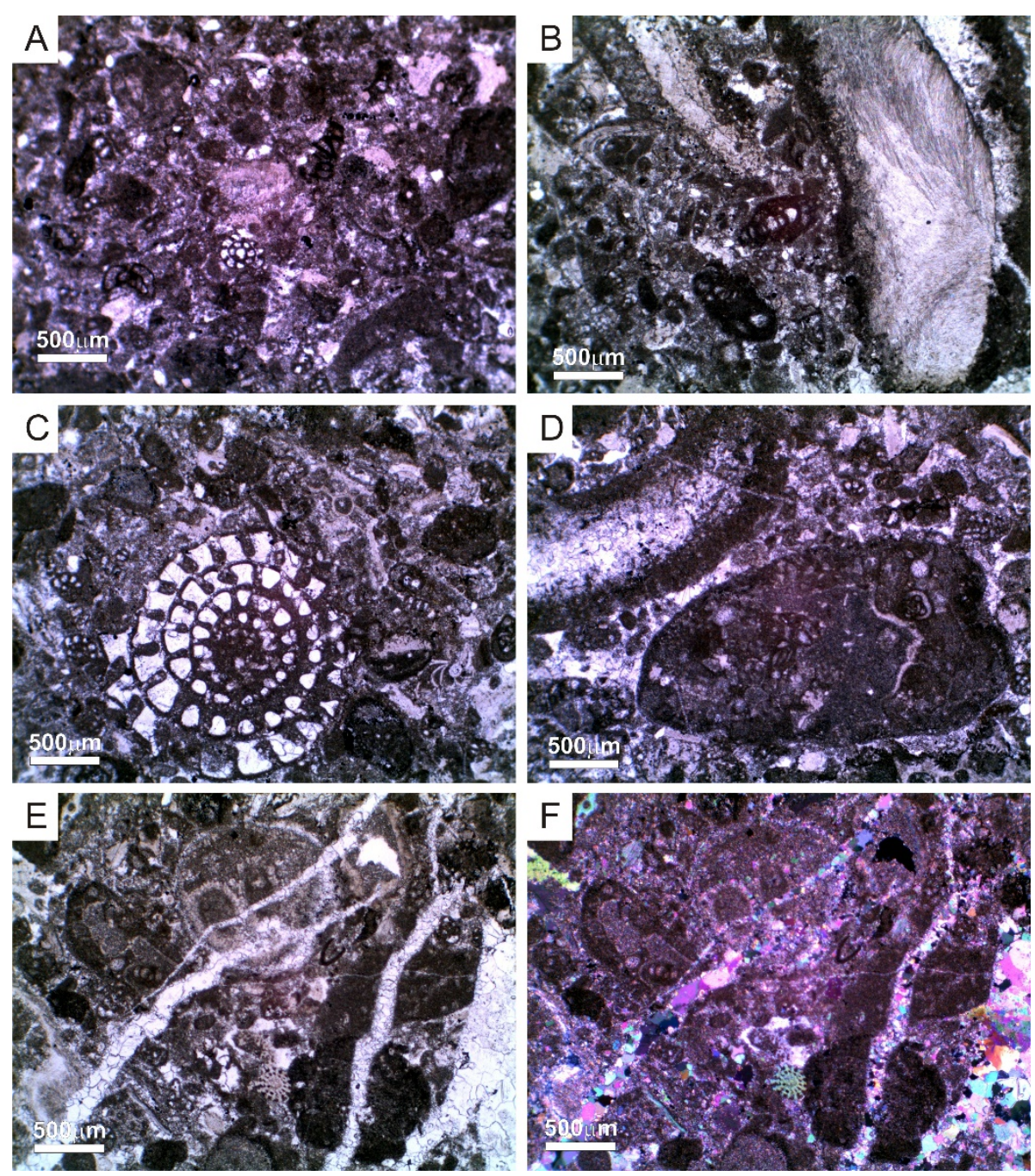

Figure 2. Optical microphotographs of intact 'Prada' limestone. (A) Grain-supported texture composed of bioclasts,

angular and sub-angular grains of quartz and sub-rounded grains of iron sulphides. Details of (B) molluscs, (C)

foraminifera and (D) red algae. (E-F) Bioclasts and micritic matrix cut by calcite veins. Microphotographs were taken under (A-E) parallel-nicols and (F) crossed-nicols

Observations using SEM allowed identify two different textures on 'Prada' limestones: dark and light grey. Samples with a dark grey texture showed a higher concentration of pyrite, quartz and fissures (Figure 3a) than those with a light grey aspect (Figure 3b). Fissures were mainly intergranular and did not show a preferred orientation. Pyrite appeared with both cubic and well-formed framboidal (raspberry like aggregates of pyrite spheres) geometries (Figure 3c) at $105^{\circ} \mathrm{C}$ with different sizes and distribution. Such structures evolved to incomplete framboids when heated to $500^{\circ} \mathrm{C}$ (Figure 3d). EDX 
analysis was performed over different framboidal structures. Thus, a structure heated to $105^{\circ} \mathrm{C}$ was formed mainly by Fe (30.97\%) and S (34.48\%), and a small fraction of $\mathrm{O}$ (4.78\%), while another structure when heated to $500^{\circ} \mathrm{C}$ showed increased values for Fe (65.83\%), a severe decrease in S (2.66\%), and an appreciable increase in O (75.51\%).

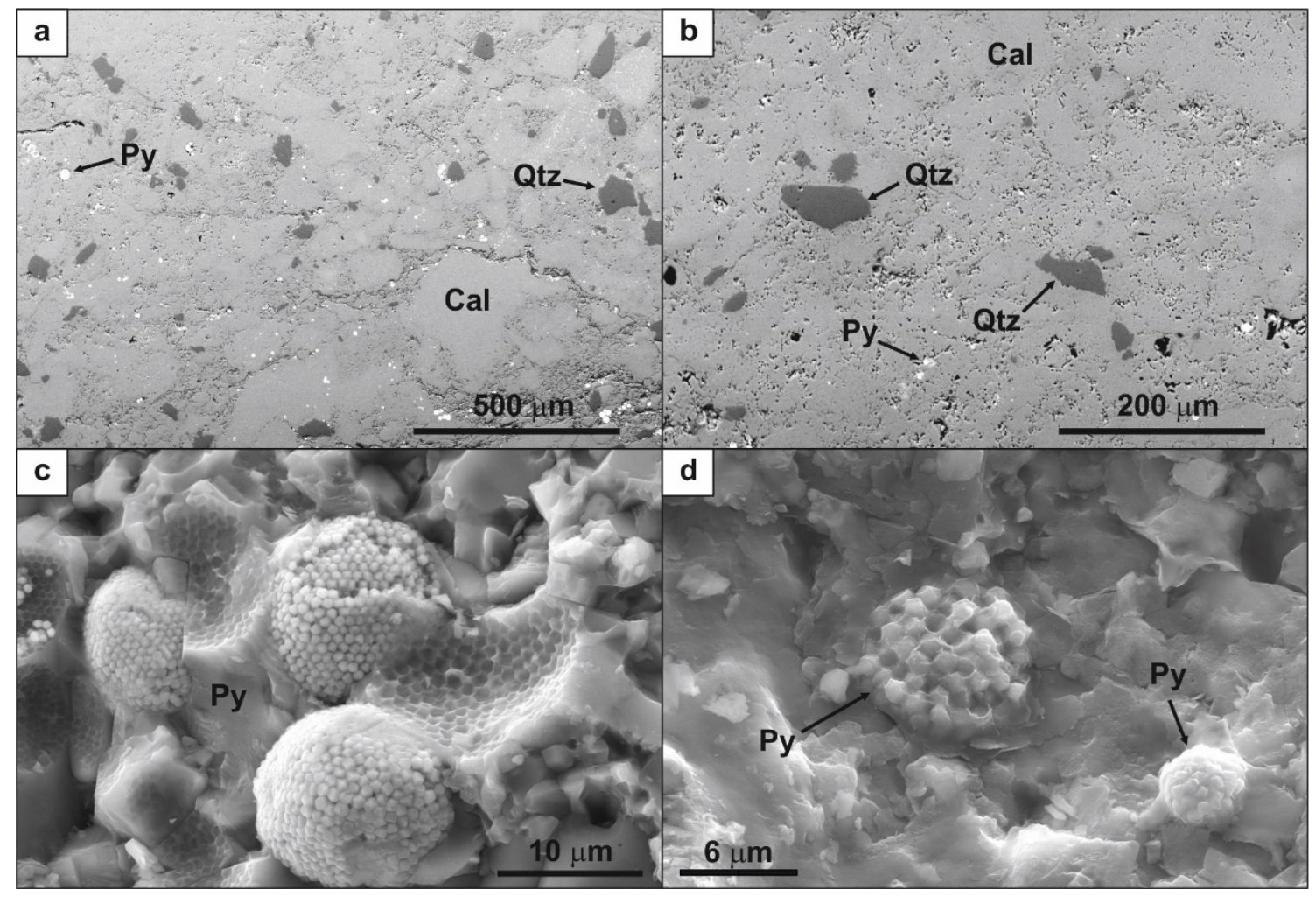

Figure 3. Images from scanning electron microscope of a dark grey sample (a) and a light grey sample (b) before thermally treated, showing different content of pyrites, quartz, and fissure distribution. Well-formed pyrite framboids appeared in dark grey samples heated to $105^{\circ} \mathrm{C}$ (c). Pyrite framboids showed uncomplete when heated to $500^{\circ} \mathrm{C}$ (d)

Chemical composition (expressed as weight percent) is different for both textures (Table 2). Dark grey texture presented $\mathrm{SiO}_{2}(9.27 \%)$, what is coherent with grains of monocristaline quartz referred above, and other oxide combinations such as $\mathrm{Al}_{2} \mathrm{O}_{3}(2.74$ $\%), \mathrm{Fe}_{2} \mathrm{O}_{3}(1.33 \%)$ and $\mathrm{K}_{2} \mathrm{O}(0.49 \%)$ related to a clay fraction in the limestone. Sulphur was present in the dark texture $(0.85 \%)$, partly forming sulphide $(0.60 \%)$, and organic matter was also present (1.16\%). Moreover, light grey limestones showed residual or inexistent percentages of quartz and clay minerals, sulphide and organic matter, while 
percentages of $\mathrm{CaO}$ and $\mathrm{C}$ were slightly greater than in the dark texture. Results for dark grey limestones after calcination at $500^{\circ} \mathrm{C}$ revealed decreases in the total amount of sulphur, sulphide, total carbon and calcium, and an increase in quartz and clay compounds.

Table 2. Compounds registered on light and dark grey samples

\begin{tabular}{|c|c|c|c|}
\hline \multirow{2}{*}{$\begin{array}{c}\text { Compound } \\
\text { (\%) }\end{array}$} & Light grey simples & \multicolumn{2}{|c|}{ Dark grey samples } \\
\cline { 2 - 4 } & $105^{\circ} \mathrm{C}$ & $105^{\circ} \mathrm{C}$ & $500^{\circ} \mathrm{C}$ \\
\hline $\mathrm{CaO}$ & 54.30 & 46.60 & 40.70 \\
\hline $\mathrm{Al}_{2} \mathrm{O}_{3}$ & 0.11 & 2.74 & 3.62 \\
\hline $\mathrm{SiO}_{2}$ & 0.65 & 9.27 & 11.55 \\
\hline $\mathrm{Fe}_{2} \mathrm{O}_{3}$ & 0.19 & 1.33 & 1.52 \\
\hline $\mathrm{K}_{2} \mathrm{O}$ & 0.02 & 0.49 & 0.65 \\
\hline $\mathrm{C}_{\text {total }}$ & 11.80 & 10.20 & 9.87 \\
\hline $\mathrm{S}_{\text {total }}$ & 0.01 & 0.85 & 0.76 \\
\hline Sulphide & - & 0.60 & 0.47 \\
\hline Organic matter & 0.11 & 1.16 & - \\
\hline
\end{tabular}

Results using XRD on dark grey samples before and after heat treatment enabled the determination of a greater proportion of pyrites (expressed as percentage by weight) in the intact rock (1.5\%), and a decrease after heating to $500^{\circ} \mathrm{C}(1.2 \%)$. The presence of hematite was also registered after heat treatment on dark grey samples (0.6\%). It is worth noting that XRD can only characterise crystalline solid phases and consequently any possible amorphous phase formed by the pyrite oxidation would be not detected using this technique.

TG-DTA-DSC and TG-DTA-MS experiments on dark grey samples were conducted up to $700^{\circ} \mathrm{C}$, and allowed the identification of three different stages (Figure 4), involving the generation of different chemical compounds. Stage I $\left(100<\mathrm{T}<200^{\circ} \mathrm{C}\right)$ showed an initial release of $\mathrm{H}_{2} \mathrm{O}$ (Figure 4a). Stage II $\left(400<\mathrm{T}<600^{\circ} \mathrm{C}\right)$ revealed a greater release of $\mathrm{H}_{2} \mathrm{O}$ (Figure 4b), as well as of $\mathrm{CO}_{2}$ (Figure $4 \mathrm{~d}$ ), with a peak at above $520^{\circ} \mathrm{C}$. Also the release 
of $\mathrm{SO}_{2}$ was recorded in a narrow range of temperatures, between 405 and $535^{\circ} \mathrm{C}$, and showed a marked peak at $460^{\circ} \mathrm{C}$ (Figure 4c). Finally, stage III $\left(\mathrm{T}>600^{\circ} \mathrm{C}\right)$ showed an increasing release of $\mathrm{CO}_{2}$ with temperature (Figure 4d). Results on TG curve (Figure 4a) revealed a small weight loss in stages 1 and 2 (less than $0.5 \%$ in weight). DSC curve confirmed that reactions taking place on stage 2 are exothermic.

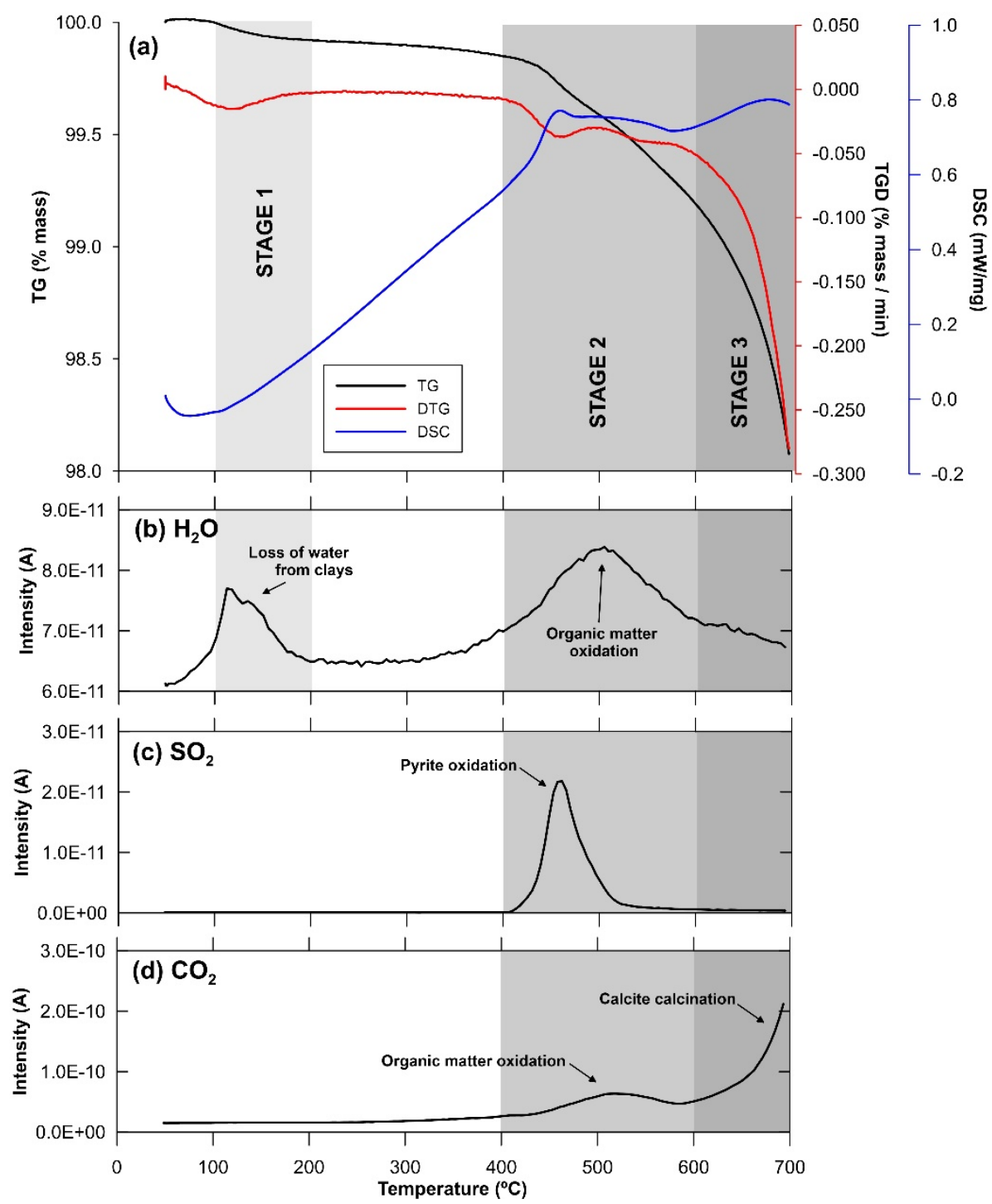

Figure 4. TG-DTA-DSC curves for the dark limestone (a) and MS curves for $\mathrm{H}_{2} \mathrm{O}$ (b), $\mathrm{SO}_{2}$ (c) and $\mathrm{CO}_{2}$ (d)

MIP analysis reflected dual porosity features on dark grey samples (Figure $5 a$ ), which is in concordance with the textural characterisation. The first pore family represents the interparticle porosity defined by grain minerals, cements, and fine-grains and shows a 
small pore size (in the pore range of 0.01-0.2 $\mu \mathrm{m}$ ). A second pore family represents micro-fissures, which are more numerous, and appear in larger sizes $(>200 \mu \mathrm{m})$ that MIP cannot measure completely. Otherwise, light grey samples showed interparticle porosity with greater pore size (lower than $1 \mu \mathrm{m}$ ), and very few micro-fissures (Figure 5b).

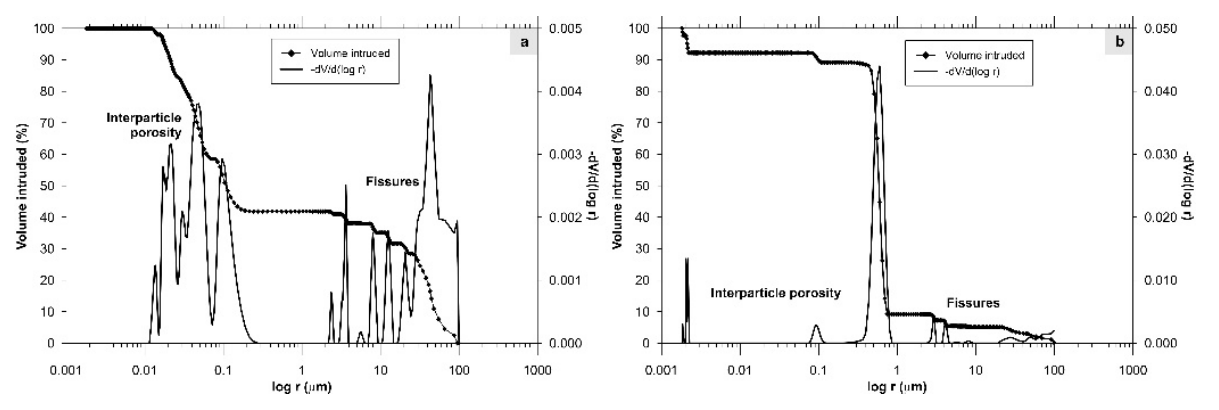

Figure 5. Cumulative mercury intrusion and pore size distribution curves of dark (a) and light grey (b) textures before thermally treated.

\subsection{Variation of physical properties by thermal treatment}

Some dark grey samples exploded inside the furnace when heated at $400^{\circ} \mathrm{C}$ and $500^{\circ}$ C exhibiting a total loss of structure and causing fragments spread over the furnace (Figure $6 a, d, f, h$ ), displacement, overturn or damage of the surrounding samples by fragments impacts (Figure 6f), and even the embedding of some rock pieces in the walls of the furnace (Figure 6a,b). We also perceived the sound of rock fragments impacting inside the furnace. It occurred instantly, and such impacts were violent enough to be clearly heard in the laboratory. Consequently, for the subsequent heating rounds the samples were covered with a metal protection grid to avoid further damage in the furnace (Figure 6c, d, g, h). The temperatures recorded by the thermocouples were $470^{\circ} \mathrm{C}$ inside the furnace, $438^{\circ} \mathrm{C}$ on the surface of an instrumented sample, and $390^{\circ} \mathrm{C}$ in its centre in the precise moment in which we heard the explosion of one sample. It is noteworthy that, after the explosion, the room was impregnated by an intense acrid smell attributed to the release of $\mathrm{SO}_{2}$. That strong smell reached such intensity that a gas extraction 
system was needed, and we were forced to leave the room. We undoubtedly related such phenomenon with the explosive event, which due to its violence could not be confused with fracturing or splitting of the samples. Explosions were not registered for temperatures of $300^{\circ} \mathrm{C}$, neither in the light grey samples. In addition to the exploded specimens, some dark samples fractured and clearly exhibited visible cracks. Table 3 summarizes the number of dark samples that showed differing grades of damage for each temperature. The maximum number of exploded samples was registered at $500^{\circ}$ $\mathrm{C}$, although the grade of fracturing of specimens was greater at $400^{\circ} \mathrm{C}$, and not evident for temperatures lower than $300^{\circ} \mathrm{C}$ 

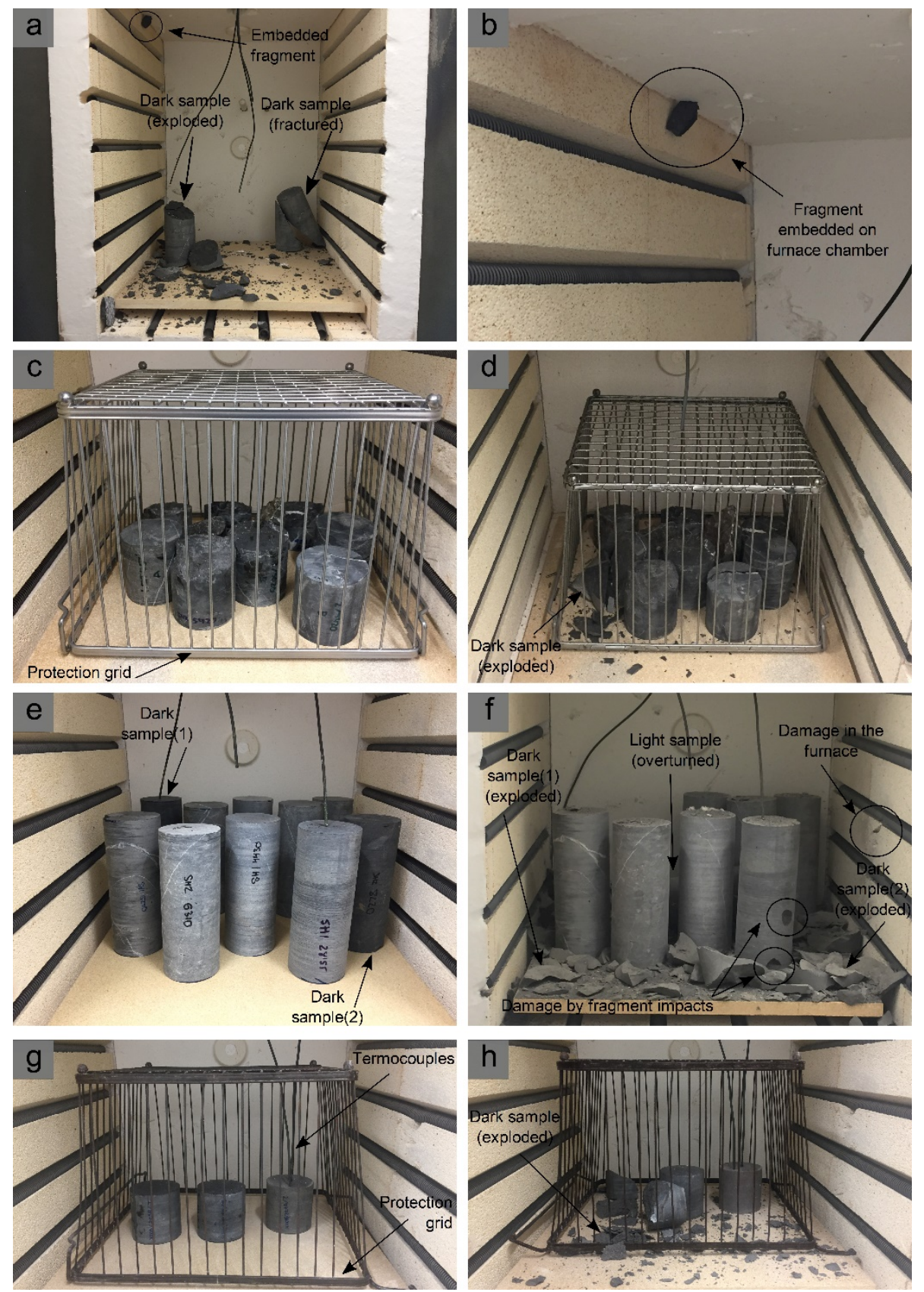

Figure 6. (a) Dark samples exploded or fractured when heated at $400^{\circ} \mathrm{C}$. (b) Detail of the fragment embedded in the furnace chamber due to the violence of the event shown in (a). Dark samples before (c) and after (d) heating at $400^{\circ} \mathrm{C}$. Note the protection grid used to preserve the furnace. Dark and light grey cores before (e) and after (f) heating at $500^{\circ}$ C. Note that only dark cores exploded, and their fragments overturned and damaged the surrounding light grey samples and the furnace chamber. A new set of dark samples before $(\mathrm{g})$ and after $(\mathrm{h})$ heating at $500^{\circ} \mathrm{C}$ using the protection grid. The temperatures were being registered using thermocouples when one sample exploded. 
Table 3. Number of samples that showed different grades of damage for each temperature.

\begin{tabular}{|c|c|c|c|}
\hline \multirow{2}{*}{$\begin{array}{c}\text { Temperature } \\
\left.\text { ( }{ }^{\circ} \mathrm{C}\right)\end{array}$} & \multicolumn{3}{|c|}{ Grade of damage } \\
\hline & Explosion & $\begin{array}{c}\text { Fracturing and visible } \\
\text { fissures }\end{array}$ & No visible damage \\
\hline 300 & 0 & 0 & 10 \\
\hline 400 & 2 & 4 & 4 \\
\hline 500 & 4 & 2 & 4 \\
\hline
\end{tabular}

Before discussing the evolution of physical and mechanical parameters with temperature of both textures, average values for the intact rock (defined at a reference temperature of $105^{\circ} \mathrm{C}$ ) are depicted (Table 4). Values of physical parameters were in the same range for both textures, while mechanical parameters (UCS, Young's modulus, and Poisson's ratio) were smaller for the dark grey samples.

Table 4. Reference values for dark and light grey samples forming 'Prada' limestone, heated at $105^{\circ} \mathrm{C}$.

\begin{tabular}{|c|c|c|}
\hline Parameter & $\begin{array}{c}\text { Dark grey } \\
\text { samples }\end{array}$ & $\begin{array}{c}\text { Light grey } \\
\text { samples }\end{array}$ \\
\hline Dry density, $\rho_{\mathrm{d}}\left(\mathrm{kN} / \mathrm{m}^{3}\right)$ & $26.80 \pm 0.24$ & $26.84 \pm 0.25$ \\
\hline Water absorption saturated $(\%)$ & $0.46 \pm 0.36$ & $0.45 \pm 0.20$ \\
\hline Unit weight of solids, $\mathrm{V}_{\mathrm{s}}\left(\mathrm{kN} / \mathrm{m}^{3}\right)$ & $27.23 \pm 0.01$ & $27.21 \pm 0.01$ \\
\hline Open porosity, $\mathrm{n}(\%)$ & $1.22 \pm 0.94$ & $1.21 \pm 0.54$ \\
\hline Total porosity, $\mathrm{n}(\%)$ & $1.60 \pm 0.89$ & $1.46 \pm 0.91$ \\
\hline P-wave velocity, $\mathrm{V}_{\mathrm{p}}(\mathrm{km} / \mathrm{s})$ & $5.76 \pm 0.05$ & $5.35 \pm 0.06$ \\
\hline S-waves velocity, $\mathrm{V}_{\mathrm{s}}(\mathrm{km} / \mathrm{s})$ & $3.11 \pm 0.02$ & $2.65 \pm 0.02$ \\
\hline Uniaxial compressive strength, $\sigma_{\mathrm{ci}}(\mathrm{MPa})$ & $103.76 \pm 59.11$ & $164.63 \pm 23.77$ \\
\hline Young's modulus, $\mathrm{E}(\mathrm{GPa})$ (from mechanical tests) & $50.65 \pm 20.44$ & $77.69 \pm 6.54$ \\
\hline Poisson's ratio, $\mathrm{v}$ (from mechanical tests) & $0.24 \pm 0.06$ & $0.31 \pm 0.05$ \\
\hline
\end{tabular}

Open porosity trends were compared for both textures using normalised average values (i.e. results after heating were divided by those of the same samples obtained at the reference temperature of $105^{\circ} \mathrm{C}$ ) (Figure $7 \mathrm{a}$ ). The porosity showed little variation 
between 105 and $300^{\circ} \mathrm{C}$, and then gradually increased from $300^{\circ} \mathrm{C}$. Differences between textures appeared at 400 and $500^{\circ} \mathrm{C}$. Normalised open porosity was greater on dark grey samples $\left(2.61\right.$ at $400^{\circ} \mathrm{C} ; 3.43$ at $\left.500^{\circ} \mathrm{C}\right)$ than on light grey $\left(1.54\right.$ at $400^{\circ} \mathrm{C}$; 3.01 at $500^{\circ} \mathrm{C}$ ). Ultrasound wave velocity was also represented using normalised values. Values of P- (Figure 7b) and S-wave (Figure 7c) velocities progressively decreased with temperature for both textures, although the rate of decline accelerated between 400 and $500^{\circ} \mathrm{C}$. Differences between both textures appeared at 400 and $500^{\circ} \mathrm{C}$, since P-wave normalised velocity was smaller on dark grey samples $\left(0.84\right.$ at $400^{\circ} \mathrm{C} ; 0.57$ at $\left.500^{\circ} \mathrm{C}\right)$ than on light grey $\left(0.89\right.$ at $400^{\circ} \mathrm{C} ; 0.64$ at $\left.500^{\circ} \mathrm{C}\right)$; S-wave normalised velocity was also smaller on dark grey samples $\left(0.87\right.$ at $400^{\circ} \mathrm{C} ; 0.52$ at $\left.500^{\circ} \mathrm{C}\right)$ than on light grey $(0.93$ at $400^{\circ} \mathrm{C} ; 0.75$ at $\left.500^{\circ} \mathrm{C}\right)$. 

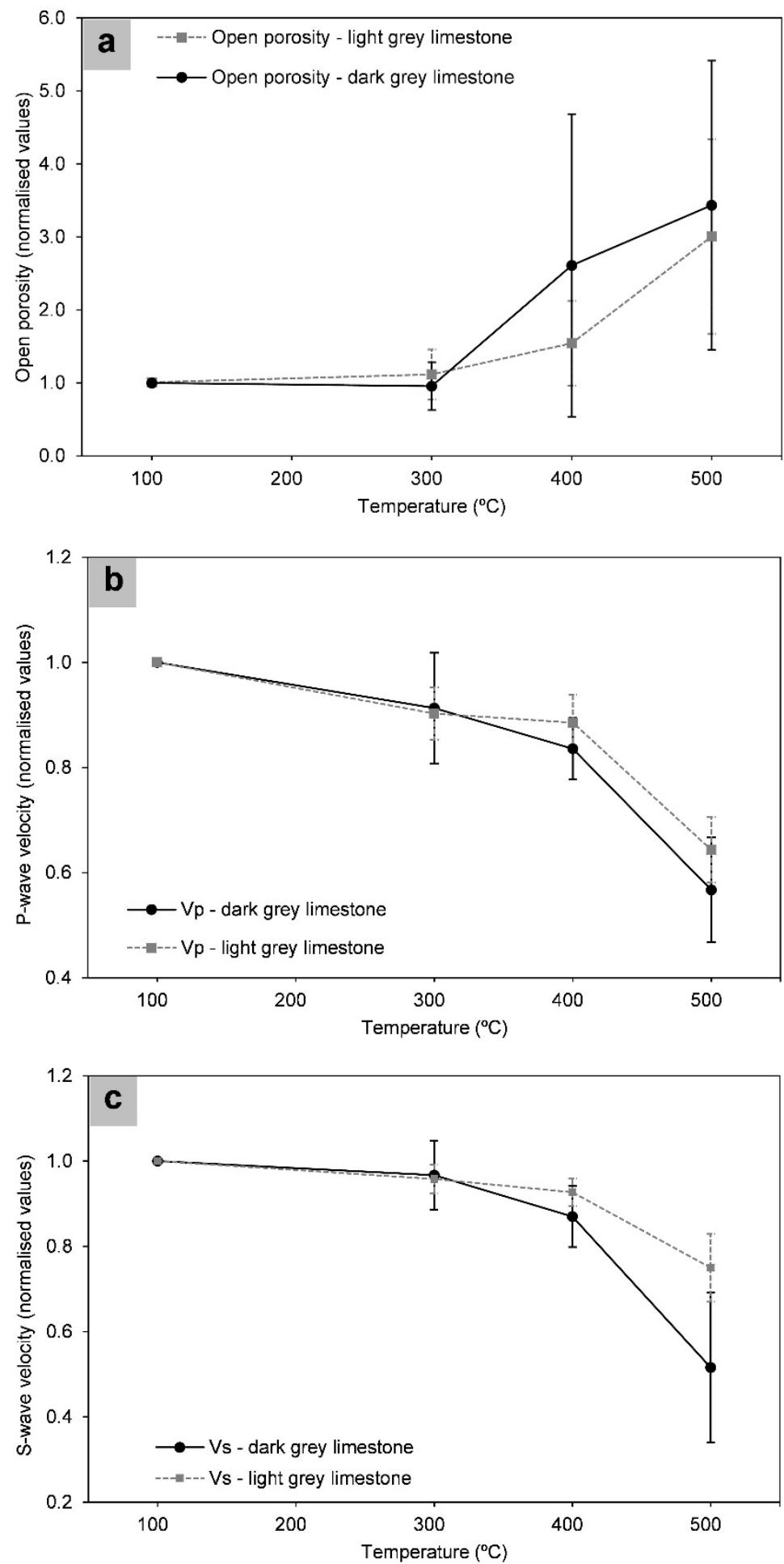

Figure 7. Variation of normalised (a) open porosity; (b) P-wave velocity; and (c) S-wave velocity of dark and light grey samples after heat treatment. Reference values used for the normalization are given in Table 4. 
Intact rock showed a bluish grey colour, with different grades of lightness: Munsell colour values varied from light bluish grey (5B 6/1) to dark bluish grey (5B 3/1). Visual observation revealed colour variation when heating: one sample at $105^{\circ} \mathrm{C}$ (Figure 8a) evolved towards red and greater luminosity when heated at $400^{\circ} \mathrm{C}$ (Figure 8b); while reddening and lightness intensified when one sample was heated from $105^{\circ} \mathrm{C}$ (Figure 8c) to $500^{\circ} \mathrm{C}$ (Figure 8d). CIELAB values enabled the trend to be quantified: lightness $L^{*}$ and colour $a^{*}, b^{*}$ increased with temperature, especially from $400^{\circ} \mathrm{C}$, with maximum values at $500^{\circ} \mathrm{C}$ (Figure 8e). The most significant variation could be observed for $\mathrm{L}^{*}$, marking a clear trend towards lighter tones with higher temperatures, especially between $400^{\circ} \mathrm{C}$ and $500^{\circ} \mathrm{C}$. In relation to colour parameter a ${ }^{*}$, a slight increasing trend could be observed up to $400^{\circ} \mathrm{C}$, and an accelerated reddening of the samples from $400^{\circ} \mathrm{C}$ to $500^{\circ} \mathrm{C}$. The parameter $\mathrm{b}$ * marked lower values than $a^{\star}$, showing an increasing trend towards yellow with temperature. 
(a) $105^{\circ} \mathrm{C}$

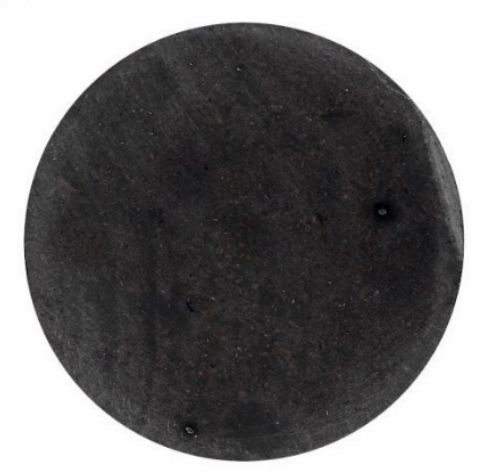

(c) $105^{\circ} \mathrm{C}$

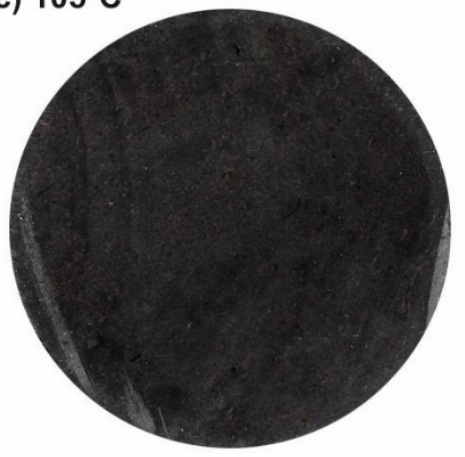

(b) $400^{\circ} \mathrm{C}$

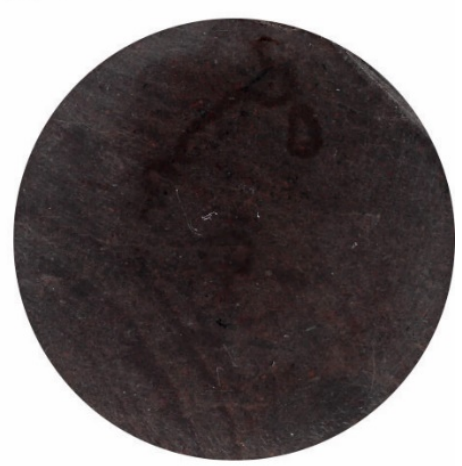

(d) $500^{\circ} \mathrm{C}$

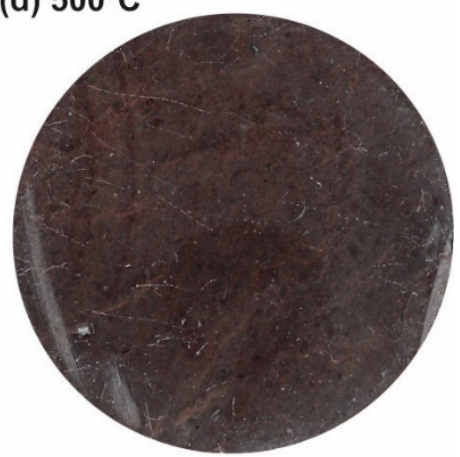

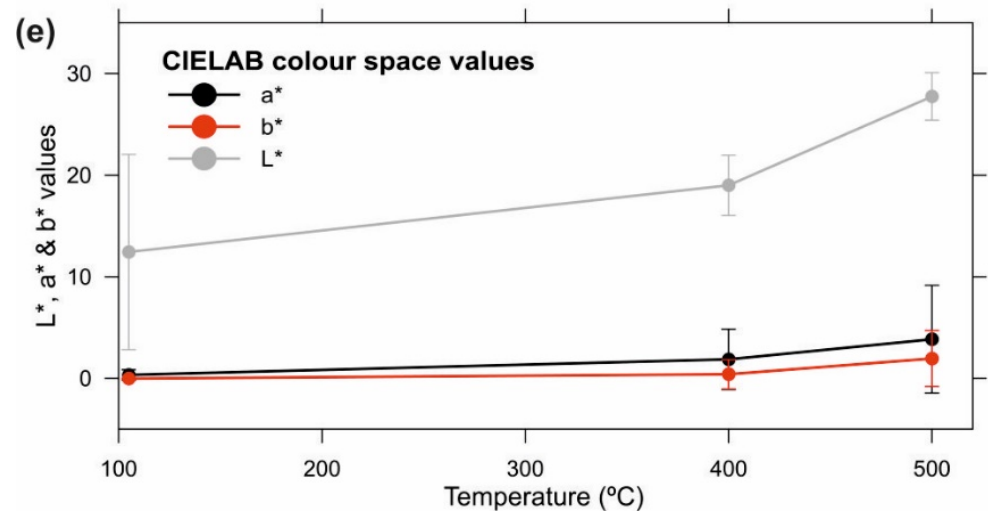

Figure 8. Compared images of the flat and polished face from one sample heated to $105^{\circ} \mathrm{C}$ (a), and later to $400^{\circ} \mathrm{C}$ (b) and from one sample heated to $105^{\circ} \mathrm{C}(\mathrm{c})$, and later to $500^{\circ} \mathrm{C}$ (d). A transition from dark grey and bluish tones to light red and increased lightness with temperature could be observed. Colour variation with temperature, expressed using CIELAB variables (e)

\section{Discussion}

In this investigation, we study two different varieties of 'Prada' limestones: (a) a dark grey texture, bearing quartz, clay, organic matter, and pyrites, and (b) a light grey texture with little or no presence of such components. Dark grey texture showed micro-porosity and 
microcracks, while light grey samples showed greater pore size and few microcracks. We have observed two negative effects of different intensity when heating the dark texture over $400^{\circ} \mathrm{C}$, not reported in the light grey texture. On the one hand, the explosion of certain samples and, on the other hand, a greater thermal damage in terms of open porosity and ultrasound wave velocity variation.

Dry density reference values are similar for dark and light grey samples, and values of open porosity at $105^{\circ} \mathrm{C}$ classify the samples as low-porosity rocks, compared to other limestones (e.g. Sengun 2014; Yavuz et al. 2010; W. Zhang et al. 2017). A growing trend in open porosity that accelerated between 400 and $500^{\circ} \mathrm{C}$ was previously reported by other authors (e.g. Yavuz et al. 2010), although values are smaller than those reported for low-porosity rocks (e.g. Sengun 2014; W. Zhang et al. 2017). Samples showed typical initial ultrasonic wave velocity values for low porous limestones (e.g. Sengun 2014; Yavuz et al. 2010), and the scatter is consistent with the observed microstructural heterogeneity in 'Prada' limestone. The decrease on P-wave velocity reflects microstructural changes produced during heating, specially between $400^{\circ} \mathrm{C}$ and $500^{\circ} \mathrm{C}$, which indicates an increase in the number and size of fissures for that interval of temperatures, for both light and dark grey textures. Although the effects of rapid cooling lead to increased thermal damage (Kim et al. 2014; Mallet et al. 2014; Kumari et al. 2018), the cooling of 'Prada' limestones was carried out at a slow rate: in a first step at a rate of 1 to $5^{\circ} \mathrm{C} / \mathrm{min}$ to $300^{\circ} \mathrm{C}$ inside the furnace, and later under ambient conditions up to room temperature. Otherwise, microstructural changes could be mainly explained by internal stress concentrations resulting from anisotropic thermal expansion of the calcite (Lion et al. 2005; Malaga-Starzec et al. 2006). However the differing evolution of open porosity, P- and S-wave velocities between textures at 400 and $500^{\circ} \mathrm{C}$ is remarkable (Figure 7), and so further additive mechanisms must be contributing on the thermal damage on the dark grey texture. 
Firstly, the thermal variation of physical properties is attributed in certain cases to the decomposition of clay minerals cementing particles or filling micopores (Zhang and LV 2020). Results in Table 4 are inconclusive and do not permit to ensure the transformation of clay compounds in the range of tested temperatures, apart from the amount of clay mineral contents is low according to the values of $\mathrm{Al}_{2} \mathrm{O}_{3}$ (Table 4).". Regarding to water content in clays, heating could lead to pore-pressure build-up when clay is organized in a continuous phase (as layers or pockets) that significantly affects the material features (Delage et al. 2000; Sultan et al. 2002; Gens et al. 2011). Indeed, for temperatures up to $200^{\circ} \mathrm{C}$ the loss of water is the main influencing factor on the thermal damage of limestones (Zhang and Lv 2020), as the high-pressure vapour escaping from the rock sample induces the generation and expansion of micro-fractures (Meng et al. 2020). TGDTA-DSC and TG-DTA-MS tests on dark grey samples allowed concentrate between 100 and $200^{\circ} \mathrm{C}$ the removal of water adsorbed on mineral surfaces and in clay minerals. However, such range of temperatures is far from 400 and $500^{\circ} \mathrm{C}$, where different thermal damage between textures was registered. Thus, we do not consider clay mineral decomposition, nor the loss of water, a reason for a greater thermal damage on the dark grey samples.

The presence of quartz on dark grey samples could also cause thermal damage in limestones by the mineral phase transition. Rocks containing quartz experiment a sudden microcracking and volume increase at the phase transition between 550 and $600^{\circ} \mathrm{C}$, with a strong peak at $573^{\circ} \mathrm{C}$ (Van der Molen 1981; Glover et al. 1995), but such mechanism cannot explain different thermal damage between textures in the range of temperatures tested $\left(T<500^{\circ} \mathrm{C}\right)$. Following with the different mineral composition between textures, thermal coefficient of calcite $\left(1.4 \times 10^{-5}{ }^{\circ} \mathrm{C}^{-1}\right)$ is less than a half than that of clay $\left(3.4 \times 10^{-5}{ }^{\circ} \mathrm{C}^{-1}\right)$ or quartz $\left(3.3 \times 10^{-5}{ }^{\circ} \mathrm{C}^{-1}\right)$ (Belmokhtar et al. 2017). Local thermal stress concentrations occur between mineral particles of different nature, due to 
mismatch in thermal expansion coefficients, thus increasing microcracking. Such effect has been reported in limestones by different authors (Liu and Xu 2013; Zhang et al. 2017b; Villarraga et al. 2018; Yang et al. 2019), and the range of temperatures of 400 to $500{ }^{\circ} \mathrm{C}$ configures a threshold for thermal cracking (Meng et al. 2020). Thus, microscale destructuring process induced by differential thermal expansion of the mineral components contribute to differences between textures when heated. Moreover, an initial micro-fissuring in the intact dark grey samples lead to greater coalescence and growth of fissures when heated, and so contributes on a greater thermal damage.

Nevertheless, existing research on thermal damage in limestones reports to microcracking, fracturing and splitting in the samples, but not to explosive events of such violence as that observed in our research. Thus, there must be additional mechanisms triggering the explosion of certain samples between 400 and $500^{\circ} \mathrm{C}$, and such mechanisms must contribute, among those discussed above, on a greater thermal damage in the dark texture in terms of open porosity and ultrasound velocity variation. For all above, we will discuss the role of organic matter and pyrite presence.

Coloration constitutes a visible difference between textures forming 'Prada' limestones. That difference seems to be caused by a greater content on organic matter in the dark grey texture, in view of the results from the potassium permanganate method: samples showed six times more organic matter. Moreover, the presence of organic matter is related to the presence of pyrites $\left(\mathrm{FeS}_{2}\right)$, which is common in continental margin sediments: these marine anoxic conditions enable bacterial sulphate reduction from organic matter that later reacts with detrital iron minerals in the sediment to form pyrite (Berner 1970, 1982). Observations using SEM confirmed framboidal pyrite structures in the group of dark grey samples, whose presence in organic matter can be a result of microbial activity (Sawlowicz 2000; Shawar et al. 2018). 
$\mathrm{XRD}$ characterisation confirmed the presence of pyrite in the dark texture, and that was corroborated with EDX analysis on the framboidal minerals. Presence of iron and sulphur was established in the chemical composition (Table 2). Therefore, a greater content of pyrites in the dark texture established an additional difference between varieties.

TG-DTA-DSC-MS analysis over dark grey samples showed three different stages (Figure 4) representing different chemical processes. Stage I $\left(100<\mathrm{T}<200{ }^{\circ} \mathrm{C}\right)$ corresponded to sample dehydration, involving removal of water adsorbed by the microporosity of mineral surfaces and in clay minerals. Stage II $\left(400<\mathrm{T}<600^{\circ} \mathrm{C}\right)$ took place between $400-600^{\circ} \mathrm{C}$ and involved two different chemical processes: TG-MS curves displayed the presence of $\mathrm{CO}_{2}$ and $\mathrm{H}_{2} \mathrm{O}$ from 400 to $600^{\circ} \mathrm{C}$, which is coherent with a thermal oxidation of organic matter (Galbács et al. 1998; Cuypers et al. 2002; Boyle 2004) that can be represented as $\mathrm{CH}_{2} \mathrm{O}_{(\mathrm{OM})}+\mathrm{O}_{2} \rightarrow \mathrm{CO}_{2}+\mathrm{H}_{2} \mathrm{O} . \mathrm{SO}_{2}$ was detected between 405 and $535^{\circ} \mathrm{C}$, showing a pronounced peak at $460^{\circ} \mathrm{C}$, which is coherent with thermal oxidation of pyrites (Hong and Fegley 1997; Gazulla et al. 2009), which can be represented as $2 \mathrm{FeS}_{2}$ (pyrite) $+11 / 2 \mathrm{O}_{2} \rightarrow \mathrm{Fe}_{2} \mathrm{O}_{3}$ (hematite) $+4 \mathrm{SO}_{2}$. Finally, stage III ( $\mathrm{T}>600^{\circ}$ C) coincides with initial stages in the decomposition of inorganic carbonate and can be written as $\mathrm{CaCO}_{3}$ (calcite) $\rightarrow \mathrm{CaO}+\mathrm{CO}_{2}$.

EDX analysis on dark grey samples after thermally treated at $500^{\circ} \mathrm{C}$ showed a clear increase in oxygen accompanied by a decrease in sulphur, and chemical results (Table 2) showed a decrease in sulphide content, which is consistent with pyrite oxidation. Moreover, thermal oxidation of pyrites results in hematite, which was confirmed by XRD results. The range of temperatures for hematite formation can be described by means of colorimetry analysis: the process of reddening limestone rocks by oxidative conditions during thermal treatment has been experimentally proven and associated with the apparition of hematite (González-Gómez et al. 2015). Indeed, a tendency towards 
reddish tones was visually appreciated between $400^{\circ} \mathrm{C}$ and $500^{\circ} \mathrm{C}$ (Figure 8), and numerically confirmed in view of CIELAB $\mathrm{a}^{*}$ values (Figure $8 \mathrm{e}$ ), which is consistent with the range of temperatures for thermal oxidation of pyrites. For all the above, in view of the results obtained using different techniques, it can be confirmed that an oxidation process of pyrites takes place, releasing $\mathrm{SO}_{2}$, when dark grey samples forming 'Prada' limestone are heated from $400^{\circ} \mathrm{C}$.

However, XRD, chemical characterisation, and framboids observed using SEM for samples heated to $500^{\circ} \mathrm{C}$ revealed that pyrite transformation was incomplete for the test conditions of temperature and time. This must be related to a lack of oxygen in the pore space. Available oxygen in pores depends on the gas diffusion coefficient, which decreases in porous materials as porosity and pore size decreases (Currie 1960). MIP results showed that dark grey limestone is a low-porosity rock with dual microstructure, which leads to poorly connected small pores. Such tortuosity strongly affects availability for gaseous transport (Benavente and Pla 2018). Consequently, air diffusion, and particularly $\mathrm{O}_{2}$ presence in pores, must be limited in dark grey samples, which explains the incomplete oxidation of pyrites. However, different conditions of volume, interstitial water content, and air exposure time, would enable greater $\mathrm{O}_{2}$ penetration throughout the rock and enable more efficient oxidation. An additional factor contributing to reduce the gas diffusion coefficient in the rock was described by Hu et al. (2006), who stated that the direct oxidation process leads to inward diffusion of oxygen due to the poreblocking effect of the formation of ferric/ferrous compounds.

The release of $\mathrm{SO}_{2}$ from $400^{\circ} \mathrm{C}$ leads to an increase in pore pressure. Moreover, thermal oxidation of organic matter, which releases $\mathrm{CO}_{2}$ and $\mathrm{H}_{2} \mathrm{O}$ specially from above $420^{\circ} \mathrm{C}$, could contribute to increase the pore-pressure. In addition, the presence of $\mathrm{CO}_{2}$ from organic matter and calcite decomposition speeds up the thermal oxidation of the pyrite 
(Lv et al. 2015; Zhang et al. 2019), which leads to a more violent chemical reaction. The DSC curve showed that thermal oxidation of pyrites and organic matter are both exothermic reactions which locally accelerate the thermal oxidation of pyrite (Figure 4). The increasing presence of $\mathrm{SO}_{2}, \mathrm{CO}_{2}$, and $\mathrm{H}_{2} \mathrm{O}$ within closed pores may cause an expansion of the rock, and so an accelerated fissuring. The observed behaviour is closely related to the initial number and distribution of micro-fissures, identified on dark samples using MIP, and their two-dimensional shape, which causes a stress concentration in their tips (Griffits 1920). Consequently, the heating of the pyrite-bearing limestone causes a nonlinear decay in physical properties, also observed in other mechanisms of physical and durability decay (Smith et al. 2008; Martínez-Martínez et al. 2013; Benavente et al. 2018). Catastrophic decay in rock integrity is a nonlinear process that dark limestones might suffer, where the initial microcracks may grow and begin to coalesce. Smith et al. (2008) argued that this situation constitutes the critical threshold for macroscopic rock integrity decay. When this critical threshold is exceeded, microcracks turn into cracks and grow rapidly. The increase in porosity may accelerate the decay in physical properties until the ultimate failure is reached."

During heating of the samples, we registered the sound of multiple impacts inside the furnace. Such impacts occurred instantly and were violent enough to be clearly heard in the laboratory. After opening the furnace, exploded samples showed a total lack of structure and its fragments were spread over the furnace, even embedded in the furnace walls as a result of the explosion. Consequently, we undoubtedly identified that sound with an explosive event, since it cannot be confused with fracturing or splitting of the samples. Additionally, we reported the exact temperatures at the moment of that explosion: $390^{\circ}$ in the centre of the sample and $438^{\circ} \mathrm{C}$ on its surface. Considering that the $\mathrm{SO}_{2}$ generation curve starts at $405^{\circ} \mathrm{C}$ and peak is at $460^{\circ} \mathrm{C}$, temperatures in the sample were compatible with the rising branch of the curve. Consequently, the release 
of $\mathrm{SO}_{2}$ must have been taking place within the sample at an accelerated rate. Additionally, there are more indicators of that event, since produced $\mathrm{SO}_{2}$ was released throughout the room immediately after the explosive event, detaching a strong smell that made necessary the use of gas extraction means and forced us to leave the room. The release of $\mathrm{SO}_{2}$ above a narrow range of temperatures would cause a peak in pore pressure that, jointly with a structure of micro-fissures in the dark texture, would cause a violent fracturing of the material. For all above, we associate the documented explosive phenomenon to $\mathrm{SO}_{2}$ production rather than oxidation of organic matter for the next reasons: (i) oxidation of pyrites evolves in a narrower temperature range than organic matter; and (ii) the peak release of $\mathrm{SO}_{2}$ occurs at lower temperatures (above $460^{\circ} \mathrm{C}$ ) than organic matter (above $520^{\circ} \mathrm{C}$ ). Moreover, explosive behaviour similar to that described in this work are not described in the existing scientific literature on the thermal effects on carbonate rocks containing organic matter (Yavuz et al. 2010; Andriani and Germinario 2014; González-Gómez et al. 2015). Consequently, thermal oxidation of pyrites has a greater contribution in the explosive phenomenon than organic matter oxidation.

Regarding the thermal damage suffered by the dark texture in terms of open porosity and ultrasound wave velocity variation, the partial contribution of the pore overpressure and gas release caused by the thermal oxidation of pyrites on the total thermal damage is difficult to evaluate. However, we cannot ignore this process because the release curve of $\mathrm{SO}_{2}$ has been identified, and their negative effects observed (i.e. the explosion of certain samples). Summarizing, in this work we describe a new thermo-chemical process to explain the observed thermal damage on dark texture limestones from Prada formation based on the thermal oxidation of pyrites, jointly with further factors identified in this research (i.e. differential thermal expansion of the mineral components and initial micro-fissuring in the intact rock). 
Finally, a $40 \%$ of the dark samples did not undergo visible damage after heat treatment although they suffered thermal damage after heat treatment according to the variation of their physical properties (Figure 7). 'Prada' limestone presents a great chemical and textural heterogeneity that varies within and between samples. Hence, pyrite content and initial micro-fissure and pore structure (that determines the gas transport and the oxidation reaction efficiency) would induce a particular explosive potential to each sample. Although our results are definitive and are based on evidences, further investigations would be necessary to quantitatively relate pyrite content and initial microfissure with explosive potential to each sample. Nevertheless, heterogeneity hinders any systematic investigation because of chemical and textural test are destructive, and therefore are not compatible with the need to count with intact samples to monitor their explosive behaviour during heating process. Despite of such difficulties, only a systematic study would be fully conclusive.

\section{Conclusions}

'Prada' limestone, formed by dark and light grey varieties, was subjected to temperatures of $105,300,400$ and $500^{\circ} \mathrm{C}$. We have observed two effects of different intensity when heating the dark texture above $400^{\circ} \mathrm{C}$, not reported in the light grey texture: (a) the explosion of certain samples; and (b) a greater thermal damage in terms of open porosity and ultrasound wave velocity variation. The influence of the specific features of the dark texture on such thermal effects have been discussed and the derived conclusions are listed below:

1. Two textures from 'Prada' limestone have been characterised: a dark grey texture with micro-porosity and microcracks, bearing quartz, clay, organic matter and 
pyrites, and a light grey texture with greater pore size and few microcracks, and little or no presence of such mineral components.

2. Thermal damage on 'Prada' Limestone could be mainly explained by internal stress concentrations resulting from anisotropic thermal expansion of the calcite. However, the differing evolution of open porosity, P- and S-wave velocities between textures at 400 and $500^{\circ} \mathrm{C}$ is explained by differences on their mineral and textural composition.

3. Different thermal damage between textures could be partly explained by microscale destructuring process induced by differential thermal expansion of the rock-forming minerals, and an original micro-fissuring in the intact dark grey samples leading to greater coalescence and growth of fissures. Effects from clay thermal decomposition, water loss and quartz phase transition have been also reasoned and discarded. Such mechanisms cannot explain the explosive events observed between 400 and $500^{\circ} \mathrm{C}$

4. The sound of multiple impacts was registered inside the furnace during the heating process of the samples. This process was instantly and violent enough to be clearly heard in the laboratory room. Furthermore, after opening the furnace, exploded samples showed a total lack of structure and their fragments were spread over the furnace, even embedded in the furnace walls as a result of the explosion. We undoubtedly associated that sound with an explosive event that cannot be confounded with fracturing or splitting on rocks.

5. The heating of dark texture samples revealed two thermal reactions involving gas release: thermal oxidation of pyrites $\left(\mathrm{FeS}_{2}\right)$ releasing $\mathrm{SO}_{2}$ from 400 to $520^{\circ} \mathrm{C}$, and thermal oxidation of organic matter releasing $\mathrm{H}_{2} \mathrm{O}$ and $\mathrm{CO}_{2}$ from 400 to $600^{\circ}$ C. Temperatures for rock explosion are compatible with the rising branch of the $\mathrm{SO}_{2}$ release curve, that would cause a peak in pore pressure that combined with 
the micro-fissured structure of the dark texture, would cause violent fracturing of the material.

6. We relate the explosive phenomenon to $\mathrm{SO}_{2}$ production rather than oxidation of organic matter for different reasons: oxidation of pyrites evolves in a narrower temperature range than organic matter, and the peak release of $\mathrm{SO}_{2}$ occurs at lower temperatures (above $460^{\circ} \mathrm{C}$ ) than organic matter (above $520^{\circ} \mathrm{C}$ ). Moreover, $\mathrm{SO}_{2}$ was released throughout the laboratory immediately after the explosive event.

7. Total thermal damage on the dark texture is attributed to thermal oxidation of pyrites, jointly with further factors identified in this research (i.e. differential thermal expansion of the mineral components and initial micro-fissuring in the intact rock).

8. Although results are definitive and are based on evidences, further investigations would be necessary to quantitatively relate pyrite content and initial micro-fissure with explosive potential to each sample. Despite of difficulties derived from great chemical and textural heterogeneity that varies within and between samples, only a systematic study would be fully conclusive.

The practical relevance of the observed phenomenon in underground infrastructures and mining engineering works is critical, since temperatures higher than $400^{\circ}$ could lead to explosive phenomenon on pyrite-bearing limestones, involving mass fracturing, rock integrity loss and strength decay on mining works and underground infrastructures. In addition, $\mathrm{SO}_{2}$ released into the atmosphere as a result of thermal oxidation of pyrites has a harmful effect on health (ATSDR 1998) of people involved on mining or underground construction or works, users of tunnels or emergency intervention teams in case of a fire event. Additionally, $\mathrm{SO}_{2}$ can react with other atmospheric chemical elements forming acid compounds (sulphurous or sulphuric 
acid) that corrode metals, concrete, limestone, and other materials (Kumar and Imam 2013), shortening underground structures life and increasing maintenance costs.

\section{Acknowledgements}

The authors wish to acknowledge Dr Julio Company Rodriguez from the Universitat Politècnica de València and Professor Juan Carlos Cañaveras from the University of Alicante, for their valuable help on mineralogical and petrographic description of the rock, respectively, in addition, Mr. Manuel Ángel Morilla Rubio from the Universitat Politècnica de València for his support on laboratory tests. Also Kreum SA, Ayesa SA, Infraestructures de la Generalitat de Catalunya, S.A.U., and the Lleida regional roads authority (Servei Territorial de Carreteres de Lleida, Generalitat de Catalunya) for providing rock samples. This work was supported by the Spanish Government [grant number RTI2018-099052-B-I00] and by the Department of Geological and Geotechnical Engineering, Universitat Politècnica de València.

\section{References}

Andriani GF, Germinario L (2014) Thermal decay of carbonate dimension stones: fabric, physical and mechanical changes. Environ Earth Sci 72:2523-2539. https://doi.org/10.1007/s12665-014-3160-6

ATSDR (1998) Public Health Statement - Sulfur Dioxide CAS\#: 7446-09-5. ATSDR Public Heal Statement

Behnia D, Ahangari K, Moeinossadat SR (2017) Modeling of shear wave velocity in limestone by soft computing methods. Int $\mathrm{J}$ Min Sci Technol 27:423-430. 
https://doi.org/10.1016/j.ijmst.2017.03.006

Belmokhtar M, Delage P, Ghabezloo S, Conil N (2017) Thermal Volume Changes and Creep in the Callovo-Oxfordian Claystone. Rock Mech Rock Eng 50:2297-2309. https://doi.org/10.1007/s00603-017-1238-7

Benavente D, Martinez-Martinez J, Cueto N, et al (2018) Impact of salt and frost weathering on the physical and durability properties of travertines and carbonate tufas used as building material. Environ Earth Sci 77:147. https://doi.org/10.1007/s12665-018-7339-0

Benavente D, Pla C (2018) Effect of pore structure and moisture content on gas diffusion and permeability in porous building stones. Mater Struct Constr 51:1-14. https://doi.org/10.1617/s11527-018-1153-8

Berner RA (1985) Sulphate reduction, organic matter decomposition and pyrite formation. Philos Trans R Soc London Ser A, Math Phys Sci 315:25-38. https://doi.org/10.1098/rsta.1985.0027

Berner RA (1982) Burial of organic carbon and pyrite sulfur in the modern ocean; its geochemical and environmental significance. Am J Sci 282:451-473. https://doi.org/10.2475/ajs.282.4.451

Berner RA (1970) Sedimentary pyrite formation. Am J Sci 268:1-23. https://doi.org/10.2475/ajs.268.1.1

Boyle J (2004) A comparison of two methods for estimating the organic matter content of sediments. $\quad \mathrm{J} \quad$ Paleolimnol 31:125-127. https://doi.org/10.1023/B:JOPL.0000013354.67645.df 
Brotóns V, Tomás R, Ivorra S, Alarcón JC (2013) Temperature influence on the physical and mechanical properties of a porous rock: San Julian's calcarenite. Eng Geol 167:117-127. https://doi.org/10.1016/j.enggeo.2013.10.012

Cheng H, Liu Q, Zhang S, et al (2014) Evolved gas analysis of coal-derived $\begin{array}{lllll}\text { pyrite/marcasite. } & \mathrm{J} & \text { Therm } & \text { Anal }\end{array}$ https://doi.org/10.1007/s10973-013-3595-0

CIE (1977) CIE Recommendations on Uniform Color Spaces, Color-Difference Equations, and Metric Color Terms. Color Res Appl 2:5-6. https://doi.org/doi:10.1002/j.1520-6378.1977.tb00102.x

Currie JA (1960) Gaseous diffusion in porous media Part 1. - A non-steady state method. Br J Appl Phys 11:314-317. https://doi.org/10.1088/0508-3443/11/8/302

Cuypers C, Grotenhuis T, Nierop KGJ, et al (2002) Amorphous and condensed organic matter domains: the effect of persulfate oxidation on the composition of soil/sediment organic matter. Chemosphere 48:919-931. https://doi.org/10.1016/S0045-6535(02)00123-6

Delage P, Sultan N, Cui YJ (2000) On the thermal consolidation of Boom clay. Can Geotech J 37:343-354. https://doi.org/10.1139/cgj-37-2-343

Fairhurst C, Hudson JA (1987) International society for rock mechanics commission on testing methods. Int J Rock Mech Min Sci Geomech Abstr 24:53. https://doi.org/10.1016/0148-9062(87)91231-9

Fioretti G, Mazzoleni P, Acquafredda P, Andriani GF (2018) On the technical properties of the Carovigno stone from Apulia (Italy): physical characterization and decay effects by means of experimental ageing tests. Environ Earth Sci 77:17. 
https://doi.org/10.1007/s12665-017-7201-9

Franklin J (1979) Suggested methods for determining water content, porosity, density absorption and related properties and swelling and slake- durability index properties. Int J Rock Mech Min Sci 16:141-156

Galbács G, Kántor T, Moens L, Dams R (1998) Mass spectrometric studies of thermal decomposition products of reference materials for use in solid sampling atomic spectrometry. Spectrochim Acta Part B At Spectrosc 53:1335-1346. https://doi.org/10.1016/S0584-8547(98)00177-3

García Senz J, Muñoz JA, Cabrera L, Universitat de Barcelona. Departament de Geodinàmica i Geofísica. (2002) Cuencas extensivas del cretácico inferior en los Pirineos centrales, formación y subsecuente inversión. Universitat de Barcelona

Gazulla MF, Gómez MP, Orduña M, et al (2009) Sulfur Determination in Geological Samples Based on Coupled Analytical Techniques: Electric Furnace-IC and TGAEGA. Geostand Geoanalytical Res 33:71-84. https://doi.org/10.1111/j.1751908X.2008.00902.x

Gens A, Vaunat J, Garitte B, Wileveau Y (2011) In situ behaviour of a stiff layered clay subject to thermal loading: observations and interpretation. In: Stiff Sedimentary Clays. Thomas Telford Ltd, London, pp 123-144

Glover PWJ, Baud P, Darot M, et al (1995) $\alpha / \beta$ phase transition in quartz monitored using acoustic emissions. Geophys J Int 120:775-782. https://doi.org/10.1111/j.1365246X.1995.tb01852.x

Gómez-Tena MP, Machí C, Gilabert J, Zumaquero E (2014) Methodologies for the detection and quantification of pyrite in clay raw materials. Congr Mund La Calid 
Del Azulejo Y Del Paviment Ceram Qualicer

González-Gómez WS, Quintana P, May-Pat A, et al (2015) Thermal effects on the physical properties of limestones from the Yucatan Peninsula. Int J Rock Mech Min Sci 75:182-189. https://doi.org/10.1016/j.ijrmms.2014.12.010

Griffits AA (1920) The phenomena of rupture and flow in solids. Masinovedenie 221:163195. https://doi.org/10.1098/rsta.1921.0006

Hansen JP, Jensen LS, Wedel S, Dam-Johansen K (2003) Decomposition and oxidation of pyrite in a fixed-bed reactor. Ind Eng Chem Res 42:4290-4295. https://doi.org/10.1021/ie030195u

Hong Y, Fegley B (1997) The kinetics and mechanism of pyrite thermal decomposition. Berichte der Bunsengesellschaft für Phys Chemie 101:1870-1881. https://doi.org/10.1002/bbpc.19971011212

Hu G, Dam-Johansen K, Wedel S, Hansen JP (2006) Decomposition and oxidation of pyrite. Prog Energy Combust Sci 32:295-314. https://doi.org/10.1016/j.pecs.2005.11.004

Kim K, Kemeny J, Nickerson M (2014) Effect of Rapid Thermal Cooling on Mechanical Rock Properties. Rock Mech Rock Eng 47:2005-2019. https://doi.org/10.1007/s00603-013-0523-3

Kumar P, Imam B (2013) Footprints of air pollution and changing environment on the sustainability of built infrastructure. Sci Total Environ 444:85-101. https://doi.org/10.1016/j.scitotenv.2012.11.056

Kumari WGP, Ranjith PG, Perera MSA, Chen BK (2018) Experimental investigation of 
quenching effect on mechanical, microstructural and flow characteristics of reservoir rocks: Thermal stimulation method for geothermal energy extraction. J Pet Sci Eng 162:419-433. https://doi.org/10.1016/j.petrol.2017.12.033

Lion M, Skoczylas F, Ledésert B (2005) Effects of heating on the hydraulic and poroelastic properties of bourgogne limestone. Int J Rock Mech Min Sci 42:508520. https://doi.org/10.1016/j.jjrmms.2005.01.005

Liu S, Xu J (2013) Study on dynamic characteristics of marble under impact loading and high temperature. Int J Rock Mech Min Sci 62:51-58. https://doi.org/10.1016/j.ijrmms.2013.03.014

Lv W, Yu D, Wu J, et al (2015) The chemical role of CO2 in pyrite thermal decomposition. Proc Combust Inst 35:3637-3644. https://doi.org/10.1016/j.proci.2014.06.066

Malaga-Starzec K, Åkesson U, Lindqvist JE, Schouenborg B (2006) Microscopic and macroscopic characterization of the porosity of marble as a function of temperature and impregnation. Constr Build Mater 20:939-947. https://doi.org/10.1016/j.conbuildmat.2005.06.016

Mallet C, Fortin J, Guéguen Y, Bouyer F (2014) Evolution of the crack network in glass samples submitted to brittle creep conditions. Int J Fract 190:111-124. https://doi.org/10.1007/s10704-014-9978-9

Martínez-Martínez J, Benavente D, Gomez-Heras M, et al (2013) Non-linear decay of building stones during freeze-thaw weathering processes. Constr Build Mater 38:443-454. https://doi.org/10.1016/j.conbuildmat.2012.07.059

Meng Q-B, Wang C-K, Liu J-F, et al (2020) Physical and micro-structural characteristics of limestone after high temperature exposure. Bull Eng Geol Environ 79:1259- 
1274. https://doi.org/10.1007/s10064-019-01620-0

Nordlund E, Zhang P, Dineva S, et al (2014) Impact of fire on the stability of hard rock tunnels in Sweden. Stockholm

Pei L, Blöcher G, Milsch H, et al (2018) Thermo-mechanical Properties of Upper Jurassic (Malm) Carbonate Rock Under Drained Conditions. Rock Mech Rock Eng 51:2345. https://doi.org/10.1007/s00603-017-1313-0

Pospíšil J, Hrdý J, Hrdý J (2007) Basic methods for measuring the reflectance color of iron oxides. Optik (Stuttg) 118:278-288. https://doi.org/10.1016/j.ijleo.2006.03.020

Rossi E, Kant MA, Madonna C, et al (2018) The Effects of High Heating Rate and High Temperature on the Rock Strength: Feasibility Study of a Thermally Assisted Drilling Method. Rock Mech Rock Eng 51:2957-2964. https://doi.org/10.1007/s00603-018-1507-0

Sawlowicz Z (2000) Framboids: From their origin to application. Pr Mineral 88:1-58

Seehra MS, Jagadeesh MS (1981) A comparative study of the properties of marcasite and pyrite. AIP Conf Proc 70:448-448. https://doi.org/10.1063/1.32915

Sengun N (2014) Influence of thermal damage on the physical and mechanical properties of carbonate rocks. Arab J Geosci 7:5543-5551. https://doi.org/10.1007/s12517-013-1177-x

Shawar L, Halevy I, Said-Ahmad W, et al (2018) Dynamics of pyrite formation and organic matter sulfurization in organic-rich carbonate sediments. Geochim Cosmochim Acta 241:219-239. https://doi.org/10.1016/j.gca.2018.08.048

Sippel J, Siegesmund S, Weiss T, et al (2007) Decay of natural stones caused by fire 
damage. Geol Soc London, Spec Publ 271:139-151. https://doi.org/10.1144/GSL.SP.2007.271.01.15

Smith BJ, Gomez-Heras M, McCabe S (2008) Understanding the decay of stone-built cultural heritage. Prog Phys Geogr Earth Environ 32:439-461. https://doi.org/10.1177/0309133308098119

Sultan N, Delage P, Cui YJ (2002) Temperature effects on the volume change behaviour of Boom clay. Eng Geol 64:135-145. https://doi.org/10.1016/S00137952(01)00143-0

UNE-EN-103204 U-E (2019) Determinación del contenido de materia orgánica oxidable de un suelo por el método del permanganato de potasio

Van der Molen I (1981) The shift of the $\alpha-\beta$ transition temperature of quartz associated with the thermal expansion of granite at high pressure. Tectonophysics 73:323342. https://doi.org/10.1016/0040-1951(81)90221-3

Verron H, Sterpenich J, Bonnet J, et al (2019) Experimental Study of Pyrite Oxidation at $100{ }^{\circ} \mathrm{C}$ : Implications for Deep Geological Radwaste Repository in Claystone. Minerals 9:427. https://doi.org/10.3390/min9070427

Villarraga CJ, Gasc-Barbier M, Vaunat J, Darrozes J (2018) The effect of thermal cycles on limestone mechanical degradation. Int J Rock Mech Min Sci 109:115-123. https://doi.org/10.1016/j.jirmms.2018.06.017

Xu ZX, Wang Q, Fu XQ (2015) Thermal stability and mechanism of decomposition of emulsion explosives in the presence of pyrite. J Hazard Mater 300:702-710. https://doi.org/10.1016/j.jhazmat.2015.07.069 
Yang J, Fu L-Y, Zhang W, Wang Z (2019) Mechanical property and thermal damage factor of limestone at high temperature. Int J Rock Mech Min Sci 117:11-19. https://doi.org/10.1016/j.jirmms.2019.03.012

Yavuz H, Demirdag S, Caran S (2010) Thermal effect on the physical properties of carbonate rocks. Int J Rock Mech Min Sci 47:94-103. https://doi.org/10.1016/j.jirmms.2009.09.014

Zhang C-L, Conil N, Armand G (2017a) Thermal effects on clay rocks for deep disposal of high-level radioactive waste. J Rock Mech Geotech Eng 9:463-478. https://doi.org/10.1016/j.jrmge.2016.08.006

Zhang W, Lv C (2020) Effects of mineral content on limestone properties with exposure to different temperatures. J Pet Sci Eng 188:106941. https://doi.org/10.1016/j.petrol.2020.106941

Zhang W, Sun Q, Zhu S, Wang B (2017b) Experimental study on mechanical and porous characteristics of limestone affected by high temperature. Appl Therm Eng 110:356-362. https://doi.org/10.1016/j.applthermaleng.2016.08.194

Zhang X, Kou J, Sun C (2019) A comparative study of the thermal decomposition of pyrite under microwave and conventional heating with different temperatures. $\mathrm{J}$ Anal Appl Pyrolysis 138:41-53. https://doi.org/10.1016/j.jaap.2018.12.002 